\title{
The case for investing in young children ${ }^{1}$
}

Julius op de Beke

Robert Putnam's latest book Our Kids, was a real eye-opener for me. Putnam is the father of social capital. In his inspiring book he talks about a growing opportunity gap for the advancement of children in the U.S. society. The book contains a number of disturbing "scissor graphs" ${ }^{2}$ comparing children of parents with not more than a high school degree to children of parents who graduated from university. The graph that disturbed me most was the one where Putman analysed the situation of children living in single parent households: in 2010, $65 \%$ of children whose parents graduated from high schools were raised by a single parent compared to only $8 \%$ raised by parents holding university education, in 1960 this proportion was $19 \%$ versus 5\%. This decline in upward social mobility is not just a result of more fragile families. Putman also refers to crumbling communities and disappearing jobs combined with an alarming lack of public investment in education. Fortunately, in Europe things are not yet as extreme as in the U.S., however similar trends have been observed to emerge in many countries. Putnam's book serves as a warning signal for Europe, as it shows what happens if we ignore the rise in inequality in our societies.

The Polish education system has made a tremendous progress over the last 10 years according to the most recent OECD PISA (Programme for International Student Assessment) assessment. The score of 15 year old Polish children for mathematics is now on par with the 3 best performers in the EU. Poland gained 2.6 points

1 The original text of a plenary speech delivered at the opening plenary session of the "Investing in Children. Social Innovations for Children and Youth: Research and Practice" on October 20, 2016, at the Faculty of Economics and Sociology of the University of Łódź.

2 See: http://avidcollegeready.org/college-career-readiness/2015/9/9/welcome-back-to-our-kids.html (last accessed 04.05.2018). 
a year between 2003 and 2012 while the rest of the world, on average, remained unchanged. Poland did so by replacing the socialist system of state sorting students into vocational tracks by a more meritocratic system that allows students to make their own choices. Poland also did it relatively cheaply as the total spending on education did not rise. This is a truly remarkable achievement.

The arguments for investing more public funds into the upbringing of very young children in particular are overwhelming. They are not just about fairness but also about being economically efficient. Intervening during the early years, particularly when children come from a disadvantaged background, can prevent a lot of social misery later on in a child's life. Then problems can usually only be set right at a very high cost. This is because the brain continues developing till a child is around 5 years old. What you learn at the start of your life you will remember for the rest of your life. In particular early childhood education and care (ECEC) turns out to be very effective.

Moreover, it is also crucial for gender equality. It is a win-win strategy. Affordable quality child care makes it possible for both parents to take on a job, and we know that paid work is the best cure against child poverty. Research shows that childcare pays to a large extent for itself because the additional working mothers will pay more in taxes and social contributions.

We should also not forget that every child that does not manage to become a productive taxpaying citizen will in the end have to be supported by our welfare state and thus weaken it. This is something our ageing societies in Europe cannot afford. Poland will age much faster than most other EU MS due to your late baby boom in the 1970 ties. Future Polish pensions will largely depend on the productivity of your children. It is not surprising that the European countries with the best work life balance are the ones that invest most in their young children. This is why the Scandinavian countries, the Benelux and France have the highest fertility rates. Parents should of course be free to choose their work life balance but when affordable child care is missing, there is obviously no freedom of choice. If women are forced to choose between a child or a career, ultimately many educated women will remain childless or have only one child. This is what we observe in countries like South Korea and Japan.

The early years (0-3) are crucial in a child's development. There is a broad consensus that the experiences of very young children shape the foundations for their later life. Attendance of high-quality ECEC positively impacts all aspects of a child's development. It enhances basic cognitive skills (literacy and numeracy) that facilitate further acquisition of specific skills related to language, general knowledge and mathematics.

As more and more children have no siblings or are raised in single parent families, access to ECEC gives them an opportunity to play with other children at their age and develop their social skills. There is much evidence showing a substantial positive relationship between the quality of ECEC and children's non-cognitive development, such as pro-social behaviour, self-control and learning dispositions. 
These long-lasting effects of ECEC on socio-emotional development are even more important than the cognitive effect. In this context, quality means that there should be time for individual interaction with the child because it is the personal interaction that drives a child's development.

PISA shows that a two year part time participation (i.e. 4 mornings per week) in quality ECEC corresponds to one year of extra schooling at the age of 14. Quality ECEC is arguably the cheapest policy measure to reduce early school leaving as it can effectively compensate for the handicap of growing up in a disadvantaged family. PISA also shows that children of well-off parents are on average one year ahead in mathematics compared to children of poor parents. This trend is not just happening in Putnam's America.

Now back to child care. Already in 2002, the EU agreed on common so-called Barcelona targets for childcare capacity. The target for children under 3 is that there should be a place in a formal child care facility for at least $33 \%$ of all children. The target for all children between 3 and the mandatory school age is more ambitious and was set at $90 \%$. The biggest deficiencies are still found for the youngest age group, only 10 member states comply with the $33 \%$ and Poland is not one of them.

In 2015, 26.9\% of all children in the EU member states were considered to be at risk of poverty and social inclusion. Poverty is defined as either growing up in a household that is living on an income below $60 \%$ of the median income or in a household that is materially deprived of at least 3 out of 9 things - ranging from not having more than one pair of shoes, not having a warm meal with meat or fish every second day, not having a week of holiday a year to being behind in paying rent and utility bills, or growing up in a household where hardly anybody works.

Child poverty is highest in Romania, Bulgaria, Hungary, Latvia, Lithuania, Greece, Italy, Spain and Ireland. In Poland it is now just below the EU average at $26.6 \%$. It has come down considerably over the last 10 years. In all countries particularly children growing up in single parent households, in large families ( +3 children) and with a migrant or Roma background are at risk.

To address this problem the European Commission adopted in February 2013, as part of a larger Social Investment Package, a long awaited recommendation on "Investing in children: breaking the cycle of disadvantage". Four months later this recommendation was unanimously approved by the Council which means that every member state has voluntarily taken on a moral obligation to implement its contents.

The recommendation is rights-based, starting from the United Nations Convention on the Rights of the Child, which was ratified by all member states. It pleads for an integrated approach. Time and time again some of the worst cases of child abuse happen because there is not enough coordination between the many specialised child protection services responsible for a child at risk in a known troubled family. 
The recommendation is built around a three pillar structure. Member states are urged to step up their investment in young children by providing the following:

- Parents have access to resources - ideally in the form of paid work or family income support

- Parents have access to quality services such as early childhood education and care and health and parent counselling;

- Children should participate in legal decisions which concern them (divorce) and in afterschool activities such as culture and sports

The implementation of the IiC recommendation is monitored by the EU. During the European Semester, which is the annual policy cycle when the European Commission discusses the socio-economic reform efforts with the MS. The semester culminates in the adoption of a number of Country Specific Recommendations (CSR) by the Council of Europe. In 2016, about 20 MS received recommendations that touched on inclusive education, child care, income and support measures for families and their children.

The EU also helps with money. For the 2014-2020 programming period, 26\% of the European Social Fund, more than $€ 20$ billion, has been ring-fenced for projects in the area of social exclusion which can be used to invest in children. For Poland this means that around $€ 4$ billion, 16 billion zloty, is available for social policy (ESF: EUR 2.8 billion, FEAD: EUR 474 million, ERDF: EUR 665 million.)

However to ensure that this is aim is fulfilled, we need enough good project applications. Here NGO's can play an important role by getting in touch with local authorities and by helping them to draft good project proposals that can be approved by the Managing Authority.

Examples of good projects can be found on the EPIC website of the Commission. EPIC stands for European Platform for Investing in Children ${ }^{3}$.

Poland has currently the fastest growing economy in the EU. You are the only $\mathrm{EU}$ country that avoided the last great recession. Unemployment is now relatively low at $7 \%$ but still a driver of extreme poverty. Poland is among the few EU countries that have accomplished its EU 2020 poverty target by reducing the number of people in poverty by more than 2.2 million. This is great news. Thanks to the booming economy there are now many bottle necks on the Polish labour market. Yet many young Poles are still working hard outside of Poland. What better way is there to persuade them to come back, or not to leave in the first place, by showing them that Poland is a good place to start a family, by increasing quality childcare, parental leave and family income support? In this respect the Commission very much welcomes the plans of the Polish government, like Family 500+ and Maluch, to increase spending on child and family benefits, which at only $0.8 \%$ of GDP is among the lowest in the EU.

3 See: http://ec.europa.eu/social/main.jsp?catld=1246\&langld=en (last accessed 04.05.2018). 
When Putnam called his book Our Kids he obviously did so because his argument is that one should not just care about one's own biological children but about all other people's children as well. This is ultimately in everybody's interest and the rationale for stepping up our investment in young children.

\section{References}

Putnam R. (2016), Our kids: The American dream in crisis, New York: Simon and Schuster.

Scissor graphs retrieved from: http://avidcollegeready.org/college-career-readiness/2015/9/9/welcome-back-to-our-kids.html (last accessed 04.05.2018). 